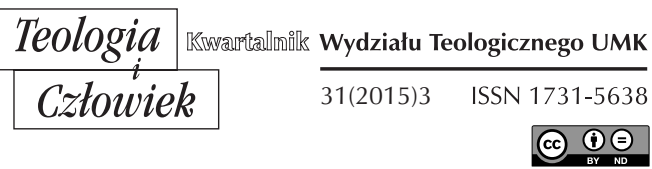

KS. MAREK JODKOWSKI*

OLSZTYN

\title{
PRÓBA NADANIA PRAW PARAFIALNYCH KATOLICKIEJ KURACJI W SUSZU NA PRZEŁOMIE XIX I XX WIEKU. PRZYCZYNEK DO BADAŃ NAD PRUSKĄ POLITYKĄ WYZNANIOWĄ
}

DOI: http://dx.doi.org/10.12775/TiCz.2015.038

WSTĘP

Dzieje katolickiej placówki duszpasterskiej w Suszu w XIX i pierwszej połowie XX wieku pozostawiły historykom niezatarty ślad w postaci archiwaliów, artykułów oraz notatek prasowych z tamtego okresu. Dotychczas jednak nie budziły one szczególnego zainteresowania naukowców. W niemieckojęzycznej monografii miasta, opracowanej przez Karla Josefa Kaufmanna w 1937 r., historię katolicyzmu na tych terenach przybliżono jedynie na kilku stronach. Z kolei w polskojęzycznym opracowaniu tej miejscowości, zredagowanej przez Janusza Cygańskiego w 2006 r., skoncentrowano się raczej na architekturze i wystroju wnętrza kościoła pw. św. Rozalii w Suszu, wybudowanego przez katolików na początku

* Ks. Marek Jodkowski - doktor historii Kościoła, magister historii sztuki i archiwista, adiunkt na Wydziale Teologii Uniwersytetu Warmińsko-Mazurskiego w Olsztynie. Zajmuje się historią kultury materialnej, historią diecezji warmińskiej, kampanologią historyczną i ikonografią chrześcijańską. 
XX wieku. Kwerenda archiwalna przeprowadzona przez autora niniejszego artykułu w Geheimes Staatsarchiv Preussischer Kulturbesitz Berlin-Dahlem oraz w Archiwum Zarządu Generalnego Stowarzyszenia św. Bonifacego, które mieści się w Bonifatiuswerk w Paderborn, pozwoliła przybliżyć czytelnikowi wybrane aspekty dziejów wspomnianej placówki ${ }^{1}$, jak też dostarczyła materiału do analizy nad nieopracowaną dotychczas próbą transformacji suskiej kuracji w pełnoprawną parafię.

We wstępie należy wspomnieć, że w XIX i pierwszej połowie XX wieku wyróżniano na obszarze Królestwa Prus różne rodzaje katolickich placówek duszpasterskich, w zależności od ich sytuacji prawnej. Definicję jednej z nich - kuracji (niem. Kuratie) przytoczono w 1870 r. na łamach „Pastoralblatt für die Diözese Ermland“. Była ona kościelną gminą (kirchliche Gemeinde), w której ustanowiony duszpasterz sprawował, w odróżnieniu od zwyczajnej, delegowaną władzę proboszczowską na polecenie biskupa. Takiego duszpasterza określano najczęściej mianem kuratusa. W spełnianiu posług kapłańskich nie różnił się niczym od właściwego proboszcza, za wyjątkiem m.in. pełnomocnictwa dotyczącego błogosławienia małżeństw, jak również formalnych procedur związanych z pogrzebem. Szereg wyjątków natomiast odnosił się do wynagrodzenia kuratusa, spraw finansowych kuracji ${ }^{2}$. Warto zaznaczyć, że parafia posiadała swoją reprezentację w sprawach urzędowych, administracyjnych i finansowych. W przypadku kuracji odpowiedzialność za jej funkcjonowanie mogła spoczywać jedynie na barkach kuratusa ${ }^{3}$. Żeby kuracja została podniesiona do rangi pełnoprawnej parafii, władze państwowe rozpatrywały przede wszystkim stan infrastruktury kościelnej danej placówki duszpasterskiej, jej liczebność, płynność finansową. Z tego względu warto skoncentrować się nad analizą dynamiki zmian statusu prawnego placówki duszpaster-

1 Zob. M. Jodkowski, Geneza i powstanie katolickiej placówki duszpasterskiej w Suszu, „Studia Warmińskie“ 2013, t. 50, s. 251-262; tenże, Przyczynek do dziejów katolickiej placówki duszpasterskiej w Suszu na przełomie XIX i XX wieku (w druku).

2 Zob. Die rechtliche Stellung der Curaten, „Pastoralblatt für die Diözese Ermland” 1870, nr 4, s. 35-37; zob. także A. Kopiczko, Duchowieństwo katolickie diecezji warmińskiej w latach 1821-1945, cz. 1, Studium prozopograficzne, Olsztyn 2004, s. 75.

${ }^{3}$ Geheimes Staatsarchiv Preussischer Kulturbesitz Berlin-Dahlem (dalej: GStA PK), XX. HA Hist. StA Königsberg, Rep. 2 Oberpräsident der Provinz Ostpreußen II, Nr 2331, k. 136. 
skiej w Suszu oraz czynnikami, które je stymulowały, zwłaszcza liczbą katolików, ale także finansami kuracji.

\section{STATUS PRAWNY PLACÓWKI DUSZPASTERSKIEJ W SUSZU}

Duszpasterz iławski - ks. Michael Czapiewski aplikował 24 sierpnia 1868 r., na podstawie suskiej ordynacji miejskiej (Städteordnung) z 1853 r. i reskryptu ministerialnego z 24 października 1855 r., o przyznanie prawa do swobodnego obrotu środków finansowych przez wspólnotę katolicką w Suszu. Władze rejencji kwidzyńskiej, jak również Ministerstwo Wyznań Religijnych, Oświaty i Zdrowia w Berlinie oddaliły prośbę przekazaną za pośrednictwem suskiego magistratu4. Tamtejszy kuratus - ks. Franz Albert Loeper, urzędujący w tym mieście od 29 czerwca 1870 r., ponowił wspomniany wniosek uzasadniając, że nieruchomość użytkowaną przez wspólnotę katolicką eksploatuje się wyłącznie w celach liturgicznych oraz jako mieszkanie duszpasterza. 14 marca 1871 r. rejencja odrzuciła podanie uzasadniając, że katolickiej wspólnocie nie przyznano osobowości prawnej ani jako samodzielnie funkcjonującej jednostce kościelnej, ani jako filii Kościoła katolickiego w Iławie $^{5}$.

W 1873 r. na prośbę katolickiej kuracji w Suszu biskup chełmiński Jan Nepomucen Marwicz ponownie wnioskował u władz państwowych o przyznanie jej praw parafialnych. Odpowiedź odmowną udzielono 9 maja 1875 r. Decyzję uzasadniano małą liczbą katolików zamieszkujących tę miejscowość i okolice. Możliwość finansowania przez nich samodzielnej placówki wydawała się również znikoma. Ponadto niewielka odległość od najbliższych świątyń katolickich pozwalała im uczestniczyć w życiu religijnym poza miejscem zamieszkania. Paradoksalnie, do wymienionych w uzasadnieniu kościołów, usytuowanych w Prabutach oraz Iławie, dzieliło suskich katolików 1ำ i 3 mile. Wskutek negatywnej decyzji władz państwowych, postanowiono zrezygnować tymczasowo z planów

${ }^{4}$ K. J. Kaufmann, Geschichte der Stadt Rosenberg in Westpreußen, Rosenberg Wpr. 1937, s. 225.

5 Tamże; zob. także M. Jodkowski, Geneza i powstanie katolickiej placówki duszpasterskiej w Suszu, s. 253. 
budowy własnego kościoła ${ }^{6}$. W lutym 1897 r. rejencja kwidzyńska nadal prezentowała stanowisko, że rozbudowa domu parafialnego w Suszu w pełni zadośćuczyni potrzebom miejscowych katolików ${ }^{7}$.

Do kolejnych prób transformacji kuracji suskiej przystąpiono z pieczołowitym przygotowaniem. 4 lutego 1900 r. przeprowadzono wybór reprezentantów wspólnoty katolickiej: Carla Posańskiego, Eduarda Michalskiego, Franza Geschke i Franza Schumilowskiego. W imieniu katolików kuracji wskazywali oni na potrzebę ustanowienia pełnoprawnej parafii. Uzasadniali swoją opinię zwiększającą się liczbą wiernych. Poza tym sceptycznie odnosili się do czterokrotnej zmiany duszpasterza w ciągu 16 lat, dopowiadając, że każdy nominowany kuratus dążył ostatecznie do objęcia placówki na obszarze diecezji, która była pełnoprawną parafią ${ }^{8}$. Akt dotyczący erygowania parafii katolickiej w Suszu (Erektionsurkunde der Pfarrei Rosenberg) zredagowano 4 września 1900 r. Świadczył on o zmieniających się planach lokalnego Kościoła względem tych obszarów. Nie ujęto w nim bowiem Kisielic, gminy wiejskiej Łęgowo, obszarów dworskich Łęgowo i Wydzierki, które zaliczano wcześniej do kuracji suskiej ${ }^{9}$. W uzasadnieniu ustanowienia parafii biskup chełmiński wskazał geograficzne położenie dotychczasowej kuracji, która charakteryzowała się zresztą znaczącą samodzielnością oraz gwarancją dalszej egzystencji. Należała ona, wraz z większą częścią powiatu morąskiego, do diecezji chełmińskiej, będąc enklawą odciętą z trzech stron przez diecezję warmińską. Do uprawomocnienia, a tym samym publicznego ogłoszenia tego rodzaju dokumentu, potrzebowano aprobaty władz państwowych, co wynikało zresztą z rozporządzenia ustanowionego 30 września $1874 \mathrm{r}$. Bez tej akceptacji dokument był jedynie projektem. Dlatego na początku $1901 \mathrm{r}$.

${ }^{6}$ F. Loeper, Mission Rosenberg, Westpreußen, Diöcese Culm, „Bonifatiusblatt” 1884, nr 4, s. 58.

${ }^{7}$ GStA PK, XX. HA Hist. StA Königsberg, Rep. 2 Oberpräsident der Provinz Ostpreußen II, Nr 2331, k. 35.

${ }^{8}$ GStA PK, XX. HA Hist. StA Königsberg, Rep. 2 Oberpräsident der Provinz Ostpreußen II, Nr 2331, k. 135v.

${ }^{9}$ GStA PK, XX. HA Hist. StA Königsberg, Rep. 2 Oberpräsident der Provinz Ostpreußen II, Nr 2331, k. 83. Tekst cytowanego aktu erekcyjnego zob.: GStA PK, XX. HA Hist. StA Königsberg, Rep. 2 Oberpräsident der Provinz Ostpreußen II, Nr 2331, k. 143-144v. 
rejencja kwidzyńska informowała nadprezydenta w Gdańsku, że biskup chełmiński przesłał wniosek o przeobrażenie kuracji suskiej w samodzielną parafię ${ }^{10}$. Niestety, odrzucono prośbę chełmińskiego ordynariusza.

Ministerstwo Wyznań Religijnych, Oświaty i Zdrowia w liście z 15 listopada 1901 r. przesłanym do nadprezydenta prowincji zachodnio-pruskiej w Gdańsku opowiedziało się za udzieleniem pozwolenia na budowę kościoła katolickiego w Suszu. Zwracano przy tym uwagę na konieczność określania inwestora budowlanego oraz podmiotu odpowiedzialnego za utrzymanie wspomnianego budynku sakralnego. Wynikało to bowiem z ustawy z 20 czerwca 1875 r. dotyczącej administrowania majątkiem we wspólnotach katolickich. Możliwość utrzymania przyszłej parafii przez jej członków wydawała się jednak znikoma. Ministerstwo sugerowało zatem ustanowienie parafii misyjnej z prawem do samodzielnego administrowania jej majątkiem zgodnie z paragrafem drugim wspomnianej ustawy ${ }^{11}$.

3 grudnia 1901 r. po raz kolejny zabiegano u władz państwowych o nadanie placówce suskiej statusu samodzielnej parafii. Zaprezentowano wówczas powyższy projekt ministerstwa, który został zaakceptowany przez stronę kościelną. Biskup chełmiński sygnował następnie dekret, który za pośrednictwem Kurii Biskupiej - opublikowano 21 lutego 1902 r. Zgodnie z jego treścią Susz stał się parafią misyjną z prawem zrzeszania wiernych i zarządzania własnym majątkiem ${ }^{12}$. Oczywiście nie były to

${ }^{10}$ GStA PK, XX. HA Hist. StA Königsberg, Rep. 2 Oberpräsident der Provinz Ostpreußen II, Nr 2331, k. 67v-68, 121; por. Archiwum Zarządu Generalnego Stowarzyszenia św. Bonifacego w Paderborn (dalej: Arch. Paderborn), Teczka: Rosenberg (25 X 1902).

${ }^{11}$ GStA PK, XX. HA Hist. StA Königsberg, Rep. 2 Oberpräsident der Provinz Ostpreußen II, Nr 2331, k. 101-102; zob. także Gesetz über die Vermögensverwaltung in den katholischen Kirchengemeinden, vom 20. Juni 1875, w: Sammlung kirchlicher Verordnungen, Erlasse und Dekrete für die Diözese Culm (1870 bis 1887), t. 2, Pelplin 1888, s. $49-65$.

12 Schematismus des Bistums Culm mit dem Bischofsitze in Pelplin 1904, Pelplin 1904, s. 264; W. Barczewski, Nowe kościoły katolickie na Mazurach, Olsztyn 1925, s. 99; K. J. Kaufmann, dz. cyt., s. 225-226; P. Romahn, Die Diaspora der Diözese Ermland, Braunsberg 1927, s. 121; A. Rzempołuch, Parafialny kościół św. Rozalii. Wybrane zagadnienia, w: Susz. Z dziejów miasta i okolic, red. J. Cygański, Olsztyn 2006, s. 104; J. Wiśniewski, Kościoły i kaplice na terenie byłej diecezji pomezańskiej 1243-1821 (1992), 
pełne prawa, jakimi cieszyła się samodzielna parafia, której przysługiwały prerogatywy finansowe gwarantowane przez państwo. Nieco wcześniej, 9 lutego 1902 r. dokonano wyboru reprezentantów miejscowej wspólnoty katolickiej; poza kuratusem - Franzem Fruede - jednogłośnie wskazano na Carla Posańskiego, Petera Krasińskiego (Kraszyńskiego, Kraszinskiego), Petera Trzaskowskiego, Eduarda Michalskiego, Augusta Tracka i Juliusa Adamka $^{13}$. Suskiej parafii misyjnej przyporządkowano katolików zamieszkujących następujące miejscowości: Susz, Babięty Małe, Babięty Wielkie, Bałoszyce, Bornice, Bronowo Małe, Bronowo Wielkie, Brusiny, Chełmżycę, Czerwoną Wodę, Falknowo, Jakubowo Kisielickie, Januszewo, Jawty Małe i Jawty Wielkie, Kamieniec, Klimy, Kołodzieje, Krzywiec, Nipkowie, Olbrachtówko, Pilichowo, Pławty Wielkie, Pólko, Redaki, Różanki, Różnowo, Solniki, Trumiejki, Ulnowo oraz Żakowice ${ }^{14}$.

Pod koniec października 1902 r. nadprezydent prowincji zachodnio-pruskiej poinformował biskupa chełmińskiego o oczekiwaniach ministra wyznań religijnych, oświaty, zdrowia dotyczących gwarancji sprawowania nabożeństw w Suszu wyłącznie w języku niemieckim, zresztą na wzór placówek duszpasterskich w Sopocie i Wrzeszczu ${ }^{15}$. Biskup Augustyn Rosentreter odpowiedział, że spełnienie tego warunku stanowiłoby działanie przeciwko istocie i charakterowi Kościoła katolickiego, który został ustanowiony dla „wszystkich narodów”. Religijne potrzeby jego wiernych należy spełniać $\mathrm{w}$ stosowny oraz najowocniejszy sposób, co z reguły realizuje się w ich ojczystym języku, konstatował biskup. Odniósł się również do przytoczonych przykładów z Sopotu, jak też Wrzeszcza. Pokreślił, że ani nie żądano od niego obietnicy używania języka niemieckiego w czasie nabożeństw w wymienionych miejscowościach, ani on sam nie wydał takiego rozporządzenia. O takiej praktyce zadecydowały czynniki demograficzne. Zdecydowana bowiem większość katolików skupionych wokół tych miejscowości posługiwała się językiem niemieckim ${ }^{16}$. Minister

cz. 1, Elbląg 1999, s. 407; W. Zawadzki, Duchowieństwo katolickie z terenu obecnej diecezji elbląskiej w latach 1821-1945, Olsztyn 2000, s. 44.

13 „Westpreußisches Volksblatt“ 1902, nr 33, z 10.02.

${ }^{14}$ K. J. Kaufmann, dz. cyt., s. 226.

15 GStA PK, XX. HA Hist. StA Königsberg, Rep. 2 Oberpräsident der Provinz Ostpreußen II, Nr 2331, k. 146v-147.

${ }^{16}$ GStA PK, XX. HA Hist. StA Königsberg, Rep. 2 Oberpräsident der Provinz Ostpreußen II, Nr 2331, k. 154-154v. 
wyznań religijnych, oświaty i zdrowia ponaglał nadprezydenta prowincji zachodnio-pruskiej w sprawie stanowiska biskupa chełmińskiego, co do gwarancji stosowania języka niemieckiego w czasie nabożeństw ${ }^{17}$. Mimo wcześniejszej opinii biskupa na ten temat, 13 marca 1903 r. nadprezydent odpowiedział ministrowi, że negocjacje są $\mathrm{w}$ toku ${ }^{18}$.

Rejencja kwidzyńska na postawie pełnomocnictwa udzielonego jej przez Ministerstwo Wyznań Religijnych, Oświaty i Zdrowia z 20 października 1900 r. zaaprobowała dekret biskupi 4 września 1903 r. Ustanowienie parafii misyjnej zostało usankcjonowane 8 listopada $1903 \mathrm{r}$. poprzez wybór 4 członków Zarządu Kościelnego oraz 11 przedstawicieli Rady Parafialnej ${ }^{19}$. Wśród członków zarządu znaleźli się Peter Krasiński, budowniczy powiatowy Carl Posański, skarbnik kasy sądowej Eduard Michalski i rządca Kossa z Jawt. Na przedstawicieli Rady Parafialnej delegowano m.in. dyrektora fabryki Sündera, asystenta poczty Stosika, przedsiębiorcę Potzicha, pracownika pocztowego Juliusa Adamka, mistrza szklarskiego Worma, woźnego sądowego Augusta Tacka, mistrza kowalskiego Łądkowskiego, listonosza Schulza oraz dwornika sądowego Panka. Pochodzili oni z Susza. Dołączono do nich również dwóch robotników Reddicha i Wichera $\mathrm{z}$ Jawt. Warto wspomnieć, że w wyborach brało udział 38 parafian $^{20}$. Biskup Rosentreter nominował proboszczem misyjnym w Suszu - dotychczasowego administratora placówki - ks. Franza Klinka. Jego kanoniczne wprowadzenie w urząd nastąpiło 7 listopada $1905 \mathrm{r}^{21}$

Przedstawiciele diecezji chełmińskiej podjęli następnie starania dotyczące transformacji parafii misyjnej w pełnoprawną parafię. Niestety, 12 listopada 1910 r. Ministerstwo Wyznań Religijnych, Oświaty i Zdrowia

${ }^{17}$ GStA PK, XX. HA Hist. StA Königsberg, Rep. 2 Oberpräsident der Provinz Ostpreußen II, Nr 2331, k. 167.

18 GStA PK, XX. HA Hist. StA Königsberg, Rep. 2 Oberpräsident der Provinz Ostpreußen II, Nr 2331, k. 167v.

19 Schematismus des Bistums Culm mit dem Bischofssitze in Pelplin 1904, dz. cyt., s. 264; K. J. Kaufmann, dz. cyt., s. 226; zob. także W. Barczewski, dz. cyt., s. 99; P. Romahn, dz. cyt., s. 121; M. Jodkowski, Przyczynek do dziejów katolickiej placówki duszpasterskiej w Suszu na przełomie XIX i XX wieku (w druku).

20 „Gazeta Toruńska” 1903, nr 266, z 18.11.

${ }^{21}$ GStA PK, XX. HA Hist. StA Königsberg, Rep. 2 Oberpräsident der Provinz Ostpreußen II, Nr 2331, k. 189. 
poinformowało biskupa Rosentretera, że ze względu na spadek liczby wiernych (z 750 w 1909 r. na 622 w 1910 r.), parafii misyjnej w Suszu nie przyznano statusu pełnoprawnej parafii ${ }^{22}$. Nie mogła zatem ubiegać się o państwowe dotacje do pensji lokalnego duszpasterza, który był raczej „tytularnym” proboszczem, uznanym wprawdzie przez władze diecezjalne (jako proboszcz misyjny), jednak pozbawionym państwowych prerogatyw finansowych. W latach dwudziestych, jak też trzydziestych XX wieku ponownie zabiegano o zgodę państwa na zmianę statusu suskiej parafii misyjnej, o czym informowali zarówno ks. Walenty Barczewski ${ }^{23}$, jak i ks. Paul Romahn ${ }^{24}$ oraz Karl Josef Kaufmann ${ }^{25}$. Niestety, nie przyniosły one spodziewanego rezultatu, skoro w elenchusach diecezji warmińskiej od 1937 r. placówkę duszpasterską w Suszu określano mianem kuracji ${ }^{26}$.

\section{LUDNOŚĆ KATOLICKA}

Władze państwowe nie przychylały się do próśb wyrażanych przez katolików dotyczących transformacji kuracji suskiej w pełnoprawną parafię, uzasadniając swoje stanowisko m.in. małą liczbą katolików zamieszkujących tę placówkę duszpasterską. Urzędnicy rejencji kwidzyńskiej w piśmie do nadprezydenta prowincji zachodnio-pruskiej z 12 lutego $1897 \mathrm{r}$. twierdzili, że spośród 32 miejscowości należących do kuracji, w pięciu nie odnotowano żadnego katolika. Poza tym na wsi miały przebywać osoby tej konfesji, których więzy z tymi obszarami były raczej luźne, a zatem wskutek migracji ich liczba podlegała wahaniom. Osiadłą i zakorzenioną ludność stanowili niemal wyłącznie ewangelicy ${ }^{27}$.

Kolejnym czynnikiem uzasadniającym nieżyczliwe stanowisko władz państwowych względem rozbudowy infrastruktury kościelnej w Suszu były sprawy narodowościowe. Rejencja kwidzyńska wychodziła

${ }^{22}$ GStA PK, XX. HA Hist. StA Königsberg, Rep. 2 Oberpräsident der Provinz Ostpreußen II, Nr 2331, k. 194.

${ }^{23}$ W. Barczewski, dz. cyt., s. 99.

${ }^{24}$ P. Romahn, dz. cyt., s. 121.

${ }^{25}$ K. J. Kaufmann, dz. cyt., s. 226.

${ }^{26}$ Zob. Direktorium Warmiense 1937, s. 32; 1938, s. 32; 1939, s. 32; 1941, s. 43.

${ }_{27}$ GStA PK, XX. HA Hist. StA Königsberg, Rep. 2 Oberpräsident der Provinz Ostpreußen II, Nr 2331, k. 34v. 
z założenia, że wzniesienie katolickiego kościoła w tym mieście stałoby się równoznaczne ze wsparciem polskości. Obawiano się, że na tych "całkowicie niemieckich terenach" (durchaus deutsche Gegend) tę inicjatywę odebrano by bardzo boleśnie ${ }^{28}$. Warto odnieść się w tym miejscu do badań Leszka Belzyta, który wykazał, że w 1890 r. w całym powiecie suskim odnotowano 3724 polskojęzycznych mieszkańców (wobec 44005 niemieckojęzycznych i 1253 dwujęzycznych), w 1900 r. - 3591 (47 599 niemieckojęzycznych i 793 dwujęzycznych), w 1905 r. - 3465 (49 304 niemieckojęzycznych i 503 dwujęzycznych), zaś w 1910 r. - 3451 (50 194 niemieckojęzycznych i 870 dwujęzycznych) ${ }^{29}$. Udział ludności polskojęzycznej w strukturze demograficznej powiatu był zatem zauważalny.

Tab. 1. Liczba katolików kuracji suskiej w latach 1887-1897

\begin{tabular}{|l|c|c|c|c|}
\hline Rok & $\begin{array}{c}\text { Całkowita liczba } \\
\text { katolików }\end{array}$ & $\begin{array}{c}\text { Liczba katolików } \\
\text { w Suszu }\end{array}$ & $\begin{array}{c}\text { Liczba katolików } \\
\text { należących do } \\
\text { stacji misyjnej } \\
\text { w Zalewie oraz } \\
\text { odbywających } \\
\text { służbę wojskową }\end{array}$ & $\begin{array}{c}\text { Liczba katolików } \\
\text { kuracji } \\
\text { mieszkających } \\
\text { poza Suszem }\end{array}$ \\
\hline 1887 & 472 & 128 & 142 & 202 \\
\hline 1888 & 511 & 132 & 140 & 239 \\
\hline 1889 & 457 & 130 & 100 & 227 \\
\hline 1890 & 540 & 132 & 106 & 302 \\
\hline 1891 & 576 & 141 & 76 & 359 \\
\hline 1892 & 650 & 138 & 99 & 413 \\
\hline 1893 & 661 & 136 & 95 & 430 \\
\hline 1894 & 667 & 139 & 101 & 427 \\
\hline 1895 & 653 & 148 & 114 & 391 \\
\hline 1896 & 760 & 175 & 117 & 458 \\
\hline 1897 & 745 & 185 & 101 & 459 \\
\hline
\end{tabular}

Źródło: GStA PK, XX. HA Hist. StA Königsberg, Rep. 2 Oberpräsident der Provinz Ostpreußen II, Nr 2331, k. 78.

${ }^{28}$ GStA PK, XX. HA Hist. StA Königsberg, Rep. 2 Oberpräsident der Provinz Ostpreußen II, Nr 2331, k. 35.

29 L. Belzyt, Sprachliche Minderheiten im preußischen Staat 1815-1914. Die preußische Sprachenstatistik in Bearbeitung und Kommentar, Marburg 1998, s. 110. 
Powyższa tabela prezentuje statystykę ludności katolickiej kuracji suskiej, którą opracował jej duszpasterz - ks. Albert Wilm. W ciągu dziesięciu lat liczba jej członków wzrosła z 472 w 1887 r. do 745 w 1897 r., czyli o $63 \%$. Tendencję malejącą $\mathrm{w}$ porównaniu z poprzedzającym rokiem zaobserwowano w latach: 1889, 1895 i 1897. Największy roczny przyrost liczby katolików odnotowano w 1896 r. (o 107 osób), w 1890 r. (83 osoby) i 1892 r. (74 osoby). W analizowanym okresie zwiększył się udział katolickich mieszkańców Susza - ze 128 wiernych w 1887 r. do 185 w 1897 r. Dość duże wahania liczbowe można zauważyć wśród katolików należących do stacji misyjnej w Zalewie oraz odbywających służbę wojskową. Największą ich liczbę stwierdzono w 1887 r. - aż 142, zaś najmniejszą w 1891 r. - jedynie 76. Na obszarach kuracji położonych poza Suszem najmniej osób deklarowało przynależność do konfesji katolickiej w 1887 r. 202, zaś najwięcej w 1897 r. - 459. Tendencje spadkowe w odniesieniu do poprzedzającego roku miały miejsce w latach: 1889, 1894 i $1895^{30}$.

W odróżnieniu od zestawień prezentowanych przez nadprezydenta prowincji zachodnio-pruskiej, w powyższej tabeli dodano do liczby katolików kuracji suskiej również żołnierzy miejscowego eskadronu kirasjerów, których służyło przeciętnie 36. Regularnie co cztery tygodnie byli oni komenderowani do uczestnictwa w katolickich nabożeństwach. Poza tym brali udział w każdej uroczystości kościelnej. Warto zaznaczyć, że zajmowali znaczącą powierzchnię użytkowanej kaplicy ${ }^{31}$. Kuratus Wilm uzasadniał konieczność budowy kościoła rozmieszczeniem ludności katolickiej na obszarze kuracji, która koncentrowała się w Suszu i w miejscowościach leżących $\mathrm{w}$ pobliżu tego miasta. W celu potwierdzenia powyższej argumentacji, przywołano statystykę prowadzoną przez kuratusa na Wielkanoc 1897 r. W Suszu wraz z terenami wokół dworca oraz żołnierzami mieszkało 218 katolików, w Nipkowiu - 22, w Jawtach Małych - 34, w Jawtach Wielkich - 76, w Bałoszycach - 82, w Ulnowie 14, zaś w Jakubowie Kisielickim - 19. W sumie w Suszu i okolicach

${ }^{30}$ Zob. także M. Jodkowski, Przyczynek do dziejów katolickiej placówki duszpasterskiej w Suszu na przełomie XIX i XX wieku (w druku).

${ }^{31}$ GStA PK, XX. HA Hist. StA Königsberg, Rep. 2 Oberpräsident der Provinz Ostpreußen II, Nr 2331, k. 78. 
odnotowano aż 470 katolików. Do tego należało doliczyć mieszkańców Chełmżycy, Redaków i Różanki z 70 osobami tej konfesji, a także ok. 50 osób z innych miejscowości. Poza tym wszyscy katolicy z Łęgowa i Kisielic, którzy należeli do placówek duszpasterskich w Szwarcenowie i Świętych, od dawna brali udział w nabożeństwach w Suszu, ponieważ we wcześniej wymienionych kościołach głoszono kazania, a także śpiewano wyłącznie w języku polskim ${ }^{32}$.

Rejencja kwidzyńska informowała w 1899 r., że w 35 miejscowościach, które miały wejść w skład przyszłej parafii suskiej, mieszka 456 dorosłych i 298 dzieci konfesji katolickiej. Do tego należało doliczyć katolickich żołnierzy z załogi suskiego eskadronu kirasjerów, których liczba, zgodnie $\mathrm{z}$ informacjami uzyskanymi od administracji wojskowej, wynosiła przeciętnie 33. Oprócz tego na opisywanych obszarach przebywała pokaźna liczba polskojęzycznych robotników sezonowych. Ogólnie, na terenie planowanej parafii katolickiej odnotowano 950-1000 katolików. Podkreślano jednak, że 76 osób tego wyznania zamieszkujących Kołodzieje, Pilichowo, Trumiejki i Wydzierki, w przypadku wybudowania kościoła w Suszu, nadal będzie uczęszczało na nabożeństwa do Prabut, z powodu mniejszej odległości ${ }^{33}$. Podobnej praktyki spodziewano się po ok. 77 katolikach z Kisielic, Pławt Wielkich i Żakowic, którzy wskutek planowanej budowy linii kolejowej mieliby ułatwiony dostęp do Prabut. Konstatowano, że dotychczasowa kaplica nie odpowiada zwiększającej się liczbie katolików kuracji ${ }^{34}$. Wyraźnie jednak zaznaczano, że budowa kościoła katolickiego przyczyni się nie tyle do wzrostu liczby niemieckojęzycznej ludności robotniczej, co raczej spowoduje pomnożenie i umocnienie polskojęzycznej części opisywanej społeczności. Władze państwowe obawiały się, że wprowadzenie języka polskiego do nabożeństw celebrowanych w nowo erygowanej parafii suskiej spowoduje stopniowe zakorzenienie się tej praktyki ${ }^{35}$.

${ }^{32}$ GStA PK, XX. HA Hist. StA Königsberg, Rep. 2 Oberpräsident der Provinz Ostpreußen II, Nr 2331, k. 79.

${ }^{33}$ GStA PK, XX. HA Hist. StA Königsberg, Rep. 2 Oberpräsident der Provinz Ostpreußen II, Nr 2331, k. 55-55v.

${ }^{34}$ GStA PK, XX. HA Hist. StA Königsberg, Rep. 2 Oberpräsident der Provinz Ostpreußen II, Nr 2331, k. 56.

${ }^{35}$ GStA PK, XX. HA Hist. StA Königsberg, Rep. 2 Oberpräsident der Provinz Ostpreußen II, Nr 2331, k. 58. 
W czerwcu 1901 r. rejencja kwidzyńska określiła liczbę członków przyszłej parafii na 475 (265 dorosłych i 210 dzieci) ${ }^{36}$. W 1903 r. landrat powiatu suskiego przesłał zawiadomienie do rejencji, że znacznie zawyżono liczbę wiernych należących do opisywanej placówki duszpasterskiej ${ }^{37}$. Przy okazji ponownie skoncentrowano się nad uprzedzeniami narodowościowymi. Okazało się bowiem, że właściciel majątku rycerskiego z Orłowa -Kazimierz Slaski nabył nieruchomość ziemską w Jawtach Wielkich, którą rzekomo miał zamiar podzielić pomiędzy polskojęzycznych osiedleńców. Landrat donosił, że wprawdzie majątek nie uległ parcelacji, jednak Slaski stopniowo zastępował niemieckich robotników polską ludnością. Obawa przed polonizacją stawiała w niekorzystnym świetle coraz bardziej utożsamianą z tym procesem katolicką placówkę duszpasterską ${ }^{38}$. Pod koniec lipca 1903 r. biskup chełmiński Augustyn Rosentreter informował nadprezydenta prowincji zachodnio-pruskiej - Clemensa von Delbrücka, że do kuracji suskiej należy 968 katolików, z czego 377 to dzieci poniżej czternastego roku życia ${ }^{39}$.

\section{FINANSE SUSKIEJ PLACÓWKI DUSZPASTERSKIEJ}

Rejencja kwidzyńska sprzeciwiała się w 1897 r. budowie kościoła katolickiego w Suszu wskazując na niewydolność finansową placówki, co miała obrazować poniższa tabela.

${ }^{36}$ GStA PK, XX. HA Hist. StA Königsberg, Rep. 2 Oberpräsident der Provinz Ostpreußen II, Nr 2331, k. 81v.

${ }^{37}$ GStA PK, XX. HA Hist. StA Königsberg, Rep. 2 Oberpräsident der Provinz Ostpreußen II, Nr 2331, k. 170. Wykaz miejscowości wraz z liczbą mieszkających w nich katolików z 1904 r., należących do suskiej parafii misyjnej podano w: Schematismus des Bistums Culm mit dem Bischofssitze in Pelplin 1904, dz. cyt., s. 265.

${ }^{38}$ GStA PK, XX. HA Hist. StA Königsberg, Rep. 2 Oberpräsident der Provinz Ostpreußen II, Nr 2331, k. 174.

${ }^{39}$ GStA PK, XX. HA Hist. StA Königsberg, Rep. 2 Oberpräsident der Provinz Ostpreußen II, Nr 2331, k. 176. 
Tab. 2. Podatki na rzecz państwa płacone przez członków kuracji suskiej w 1897 r. (wartości podatku podano w markach)

\begin{tabular}{|c|c|c|c|c|c|c|c|c|}
\hline Miejscowość & Dorośli & $\begin{array}{c}\text { Dzieci } \\
\text { poniżej } \\
14 \text { lat }\end{array}$ & $\begin{array}{c}\text { Podatek } \\
\text { docho- } \\
\text { dowy }\end{array}$ & $\begin{array}{c}\text { Domiar } \\
\text { podat- } \\
\text { kowy }\end{array}$ & $\begin{array}{c}\text { Podatek } \\
\text { grunto- } \\
\text { wy }\end{array}$ & $\begin{array}{l}\text { Poda- } \\
\text { tek od } \\
\text { budyn- } \\
\text { ków }\end{array}$ & $\begin{array}{c}\text { Podatek } \\
\text { od dzia- } \\
\text { łalności } \\
\text { przemy- } \\
\text { słowej } \\
\text { i han- } \\
\text { dlowej }\end{array}$ & $\begin{array}{l}\text { Poda- } \\
\text { tek od } \\
\text { przed- } \\
\text { się- } \\
\text {-bior- } \\
\text { stwa }\end{array}$ \\
\hline Babięty Małe & 1 & & & & & & & \\
\hline Bałoszyce & 41 & 29 & 21,90 & & & & & \\
\hline Bornice & 6 & & 5,20 & & & & & \\
\hline Bronowo & 1 & & & & & & & \\
\hline Brusiny & 4 & 1 & & & & & & \\
\hline Chełmżyna & 21 & 19 & 1,60 & & & & & \\
\hline $\begin{array}{l}\text { Jakubowo } \\
\text { Kisielickie }\end{array}$ & 14 & 5 & 8,70 & & & & & \\
\hline Januszewo & 6 & 5 & & & & & & \\
\hline Jawty Małe & 21 & 21 & 7,60 & & & & & \\
\hline Jawty Wielkie & 41 & 35 & 19,70 & & & & & \\
\hline Kamieniec & 5 & & 12,10 & & & & & \\
\hline Klimy & 5 & 6 & 9,90 & & & & 12 & \\
\hline Kołodzieje & 23 & 17 & 15,60 & & & & & \\
\hline Krzywiec & 2 & & 1,20 & & & & & \\
\hline Nipkowie & 6 & 8 & 2,40 & & & & & \\
\hline Olbrachtówko & 1 & & & & & & & \\
\hline Pilichowo & 1 & & 0,80 & & & & & \\
\hline $\begin{array}{l}\text { Pławty } \\
\text { Wielkie }\end{array}$ & 3 & & 2,20 & & & & & \\
\hline Redaki & 5 & 10 & 3,60 & & & & & \\
\hline Różanki & 4 & 11 & & & & & & \\
\hline Różnowo & 3 & & 3,50 & & & & & \\
\hline Susz & 136 & 53 & 704,60 & 16,80 & 133,18 & 114,90 & 24 & 15 \\
\hline Trumiejki & 1 & & 1,10 & & 0,58 & 0,80 & & \\
\hline $\begin{array}{l}\text { Trumiejki } \\
\text { (obszar } \\
\text { dworski) }\end{array}$ & 14 & 10 & 10,30 & & & & & 10 \\
\hline Ulnowo & 9 & 5 & & & & & & \\
\hline Wydzierki & 7 & 6 & & & & & & \\
\hline
\end{tabular}


Tab. 2. cd.

\begin{tabular}{|l|c|c|c|c|c|c|c|c|}
\hline Żakowice & 3 & & 2,10 & & & & & \\
\hline & & & & & & & & \\
\hline SUMA: & 384 & 241 & 834,10 & 16,80 & 133,76 & 115,70 & 36 & 25 \\
\hline
\end{tabular}

Źródło: GStA PK, XX. HA Hist. StA Königsberg, Rep. 2 Oberpräsident der Provinz Ostpreußen II, Nr 2331, k. 38-38v.

Powyższa tabela opracowana przez rejencję kwidzyńską wskazuje, że w wielu miejscowościach należących do kuracji suskiej mieszkała ludność katolicka, która w 1897 r. nie podlegała opodatkowaniu, a zatem jej status materialny był dość niski (np. Brusiny, Januszewo, Ulnowo, Wydzierki, i in.). Wszystkie rodzaje podatku pobierano jedynie od katolików w Suszu. Podatek gruntowy i od budynków naliczano także w Trumiejkach, podatek od działalności przemysłowej i handlowej - w Klimach, zaś podatek od przedsiębiorstw - w majątku należącym do Trumiejek. Największy podatek dochodowy płacono w Suszu - 704,60 marki, Bałoszycach - 21,90 marek i Jawtach Wielkich - 19,70 marek. Na podstawie analiz przeprowadzonych przez rejencję kwidzyńską wynika ponadto, że katolicy zamieszkujący obszary wiejskie byli przeważnie robotnikami. Płacony przez nich podatek dochodowy opiewał na jedynie 129,50 marek. Ciężar utrzymania placówki duszpasterskiej spoczywał zatem na katolikach Susza, których wartość odciąganego podatku dochodowego stanowiła 704,60 marki. Z tej sumy przychody tylko 10 osób dawały w sumie 450 marek, które pobierał fiskus. Ponieważ te osoby mogły zostać w każdej chwili przeniesione, stąd też kwestionowano ich potencjalną zdolność do finansowania placówki duszpasterskiej $^{40}$. Z drugiej strony, kuratus - Albert Wilm konstatował, że od początku funkcjonowania opisywanej stacji misyjnej zatrudniano w Suszu katolickich urzędników. Aż do jesieni 1895 r. niemal wszyscy sędziowie wyznawali wiarę katolicką. Na cztery posady sekretarskie aż trzy przypadały katolikom $^{41}$. Rejencja kwidzyńska podkreślała z kolei, że suscy katolicy nie byli w stanie opłacić budowy kościoła, a następnie go utrzymać. Zakładając nawet, że świadczenia katolików na rzecz przyszłej parafii osiągną najwyższą

${ }^{40}$ GStA PK, XX. HA Hist. StA Königsberg, Rep. 2 Oberpräsident der Provinz Ostpreußen II, Nr 2331, k. 35v.

${ }^{41}$ GStA PK, XX. HA Hist. StA Königsberg, Rep. 2 Oberpräsident der Provinz Ostpreußen II, Nr 2331, k. 80. 
stawkę, czyli 40\% wartości podatku dochodowego od sumy 834,10 marek (postulowana kwota podatku dochodowego - w rzeczywistości ściągalność tych świadczeń była niższa), jej funkcjonowaniu nie wróżono przyszłości. Kwota bowiem 333,64 marek na utrzymanie zarówno kościoła, jak i proboszcza, wydawała się zbyt niska ${ }^{42}$.

W listopadzie 1899 r. informowano, że całkowita wartość podatku dochodowego katolickich mieszkańców kuracji suskiej uległa zwiększeniu do 1074,60 marek. Podkreślano jednak, że mieszkająca na stałe ludność wiejska była niemal wyłącznie ewangelicka, podczas gdy przeważającą część katolików zatrudniano jako robotników, od których pobierano najniższe stawki podatku dochodowego bądź całkowicie zwalniano ich z tych świadczeń ${ }^{43}$. Na dodatek większe wpływy do kasy kościelnej nie oznaczały wzrostu jej dochodu. Wspólnota katolicka zamierzała bowiem zaciągnąć pożyczkę 10 000-15 000 marek na prace budowlane, stąd spodziewano się wzrostu wydatków kuracji na rzecz pokrycia zadłużenia ${ }^{44}$. Nawet gdyby kasa kościelna dysponowała kwotą 450 marek (czyli 40\% wartości podatku dochodowego pobieranego od katolików kuracji), a brakująca część budżetu budowlanego zostałaby zniwelowana dzięki dobroczynnym donacjom, o czym zapewniał biskup chełmiński w liście z 6 lipca 1898 r., placówka duszpasterska mogłaby funkcjonować tylko dzięki nadzwyczajnie dużym zapomogom. Biskup chełmiński nie zagwarantował zresztą dotacji z funduszy kościelnych. Zaznaczono także, że pokrycie brakującej kwoty do pensji proboszcza z przeznaczonych na ten cel funduszy państwowych o wartości 200000 marek - co regulował artykuł 5 i 9 ustawy o wynagrodzeniu katolickich proboszczów z 2 lipca 1898 r., a czego domagał się ordynariusz miejscowej diecezji - wydawało się niemożliwe do zrealizowania. Władze państwowe deklarowały poparcie w uzyskaniu przez przyszłego proboszcza suskiego dodatku do wynagrodzenia, jeśli wspomniany fundusz wykazywałby nadwyżkę ${ }^{45}$.

${ }^{42}$ GStA PK, XX. HA Hist. StA Königsberg, Rep. 2 Oberpräsident der Provinz Ostpreußen II, Nr 2331, k. 35v.

${ }^{43}$ GStA PK, XX. HA Hist. StA Königsberg, Rep. 2 Oberpräsident der Provinz Ostpreußen II, Nr 2331, k. 56.

${ }^{44}$ GStA PK, XX. HA Hist. StA Königsberg, Rep. 2 Oberpräsident der Provinz Ostpreußen II, Nr 2331, k. 57.

${ }^{45}$ GStA PK, XX. HA Hist. StA Königsberg, Rep. 2 Oberpräsident der Provinz Ostpreußen II, Nr 2331, k. 57v-58, 59. 
Informacje na temat dochodów kuracji suskiej, zgodnych z planem budżetowym na lata 1894-1899, zamieszczono w poniższej tabeli.

Tab. 3. Roczne dochody kuracji suskiej na podstawie planu budżetowego na lata 1894-1899

\begin{tabular}{|c|c|c|c|}
\hline Lp. & $\begin{array}{c}\text { Wartość } \\
\text { kapitału } \\
\text { (w markach) }\end{array}$ & Tytuł przychodu & $\begin{array}{c}\text { Roczna } \\
\text { wartość } \\
\text { dochodu } \\
\text { (w markach) }\end{array}$ \\
\hline I & & Z własności ziemskiej & 0 \\
\hline \multirow[t]{5}{*}{ II } & & Wsparcie finansowe: & \\
\hline & & $\begin{array}{l}\text { Pensja kuratusa, określona na } 1200 \text { marek, dotowa- } \\
\text { na częściowo przez katolików z Dorsten, częściowo } \\
\text { z diecezjalnego komitetu Stowarzyszeniaśw. Bonifa- } \\
\text { cego i Wojciecha w Pelplinie. Do tego należy doliczyć } \\
300 \text { marek prowizji z funduszu budowy kościoła oraz } \\
\text { dopłatę } 150 \text { marek z kasy diecezjalnej. }\end{array}$ & \\
\hline & & Z kasy biskupiej: & \\
\hline & & na ubezpieczenie od pożaru & 25,40 \\
\hline & & na remontu i koszty sprawowanego kultu & 60 \\
\hline \multirow[t]{11}{*}{ III } & & Prowizja od kapitału & \\
\hline & & Kasa kościelna & \\
\hline & 612,68 & $\begin{array}{l}\text { Wsparcie funduszu na rzecz organisty (kapitał zdepo- } \\
\text { nowany w powiatowej kasie oszczędnościowej w Lu- } \\
\text { bawie na } 4 \% \text { ) }\end{array}$ & 24,48 \\
\hline & 257,73 & $\begin{array}{l}\text { Wolny kapitał do dyspozycji kasy kościelnej (zdepono- } \\
\text { wany w powiatowej kasie oszczędnościowej w Lubawie } \\
\text { na } 4 \% \text { ) }\end{array}$ & 10,28 \\
\hline & & Fundacje & \\
\hline & 1693,40 & Fundacja dr. Evelta (Dr. Evelt'sche Stiftung) & \\
\hline & & $\begin{array}{l}1650 \text { marek zdeponowanych w zachodnio-pruskich } \\
\text { listach zastawnych na } 3 \frac{11}{2} \% \text { (roczny przychód } 57,75 \\
\text { marek) }\end{array}$ & \\
\hline & & $\begin{array}{l}\text { 43,40 marki zdeponowane w kasie oszczędnościowej } \\
\text { w Lubawie (roczny przychód 1,73 markę) }\end{array}$ & \\
\hline & & 59,48 marek -58 marek $=$ & 1,48 \\
\hline & 100 & $\begin{array}{l}\text { Fundacja von Pałczyńskich (v. Pałczyński’sche Sti- } \\
\text { ftung) zdeponowana w kasie oszczędnościowej w Lu- } \\
\text { bawie na } 4 \% \text { (roczny przychód } 4 \text { marki) }\end{array}$ & \\
\hline & & 4 marki $-3,40$ marki $=$ & 0,60 \\
\hline
\end{tabular}


Tab. 3. cd.

\begin{tabular}{|c|c|c|}
\hline 675,68 & Fundacja Linnemannów (Linnemann’sche Stiftung) & \\
\hline & $\begin{array}{l}375 \text { marek zdeponowanych w zachodnio-pruskich } \\
\text { listach zastawnych na } 3 \frac{1}{2} \% \text { (roczny przychód } 13,13 \\
\text { marek) }\end{array}$ & \\
\hline & $\begin{array}{l}\text { 300,68 marek zdeponowanych w kasie oszczędnościo- } \\
\text { wej w Lubawie na } 4 \% \text { (roczny przychód } 12 \text { marek) }\end{array}$ & \\
\hline & 25,13 marek $-20,13$ marek $=$ & 5 \\
\hline 398,62 & Fundacja I z Dorsten & \\
\hline & $\begin{array}{l}360 \text { marek w zachodnio-pruskich listach zastawnych } \\
\text { na 31수 (roczny przychód } 12,60 \text { marek) }\end{array}$ & \\
\hline & $\begin{array}{l}\text { 38,62 marek zdeponowanych w kasie oszczędnościo- } \\
\text { wej w Lubawie na } 4 \% \text { (roczny przychód } 1,58 \text { markę) }\end{array}$ & \\
\hline & 14,18 marek $-12,18$ marek $=$ & 2 \\
\hline 150 & $\begin{array}{l}\text { Fundacja II z Dorsten zdeponowana w zachodnio- } \\
\text {-pruskich listach zastawnych na } 3 \frac{1}{2} \% \text { (roczny przy- } \\
\text { chód 5,26 marek) }\end{array}$ & \\
\hline & 5,26 marek $-4,26$ marki $=$ & 1 \\
\hline 101,17 & Fundacja Cathariny Kayser & \\
\hline & $\begin{array}{l}60 \text { marek zdeponowanych w zachodnio-pruskich } \\
\text { listach zastawnych na } 3 \frac{1}{2} \% \text { (roczny przychód } 2,10 \\
\text { marki) }\end{array}$ & \\
\hline & $\begin{array}{l}41,17 \text { marek zdeponowanych w kasie oszczędnościo- } \\
\text { wej w Lubawie na } 4 \% \text { (roczny przychód 1,64 markę) }\end{array}$ & \\
\hline & 3,74 marki $-3,24$ marki $=$ & 0,50 \\
\hline 982,45 & Fundacja I z Raesfeld & \\
\hline & $\begin{array}{l}900 \text { marek zdeponowanych w poznańskich listach } \\
\text { zastawnych na } 4 \% \text { (roczny przychód } 36 \text { marek) }\end{array}$ & \\
\hline & $\begin{array}{l}60 \text { marek zdeponowanych w zachodnio-pruskich } \\
\text { listach zastawnych na } 3 \frac{1}{2} \% \text { (roczny przychód } 2,10 \\
\text { marki) }\end{array}$ & \\
\hline & $\begin{array}{l}\text { 22,45 marki zdeponowane w kasie oszczędnościowej } \\
\text { w Lubawie na } 4 \% \text { (roczny przychód } 0,88 \text { marek) }\end{array}$ & \\
\hline & 38,98 marek $-31,78$ marek $=$ & 7,20 \\
\hline 100 & $\begin{array}{l}\text { Fundacja Timmermannów (Timmermann'sche Sti- } \\
\text { ftung) zdeponowana w kasie oszczędnościowej w Lu- } \\
\text { bawie na } 4 \% \text { (roczny przychód } 4 \text { marki) }\end{array}$ & \\
\hline & 4 marki $-3,50$ marki $=$ & 0,50 \\
\hline 307 & Fundacja Tilków (Tilk’sche Stiftung) & \\
\hline
\end{tabular}


Tab. 3. cd.

\begin{tabular}{|c|c|c|}
\hline & $\begin{array}{l}300 \text { marek zdeponowanych w zachodnio-pruskich } \\
\text { listach zastawnych n } 3 \frac{11}{2} \% \text { (roczny przychód 10,50 } \\
\text { marek) }\end{array}$ & \\
\hline & $\begin{array}{l}7 \text { marek zdeponowanych w kasie oszczędnościowej } \\
\text { w Lubawie na } 4 \% \text { (roczny przychód 0,28 marek) }\end{array}$ & \\
\hline & 10,78 marek $-9,50$ marek $=$ & 1,28 \\
\hline 933 & Fundacja II z Raesfeld & \\
\hline & $\begin{array}{l}900 \text { marek zdeponowanych w poznańskich listach } \\
\text { zastawnych na } 4 \% \text { (roczny przychód } 36 \text { marek) }\end{array}$ & \\
\hline & $\begin{array}{l}33 \text { marki zdeponowane w kasie oszczędnościowej } \\
\text { w Lubawie na } 4 \% \text { (roczny przychód 1,32 markę) }\end{array}$ & \\
\hline & 37,32 marek $-31,32$ marek $=$ & 6 \\
\hline 2225,28 & Fundacja III z Raesfeld & \\
\hline & $\begin{array}{l}600 \text { marek zdeponowanych w poznańskich listach } \\
\text { zastawnych na 31ํ2\% (roczny przychód } 21 \text { marek) }\end{array}$ & \\
\hline & $\begin{array}{l}1575 \text { marek zdeponowanych w zachodnio-pruskich } \\
\text { listach zastawnych na 31/2\% (roczny przychód } 55,13 \\
\text { marek) }\end{array}$ & \\
\hline & $\begin{array}{l}\text { 50,28 marek zdeponowanych w kasie oszczędnościo- } \\
\text { wej w Lubawie (roczny przychód 2,60 marki) }\end{array}$ & \\
\hline & 78,73 marek $-64,73$ marki $=$ & 14 \\
\hline 165,80 & Fundacja Riechersów (Riechers'sche Stiftung) & \\
\hline & $\begin{array}{l}150 \text { marek zdeponowanych w zachodnio-pruskich } \\
\text { listach zastawnych na } 3 \frac{112 \%}{2} \text { (roczny przychód } 5,26 \\
\text { marek) }\end{array}$ & \\
\hline & $\begin{array}{l}\text { 15,80 marek zdeponowanych w kasie oszczędnościo- } \\
\text { wej w Lubawie na } 4 \% \text { (roczny przychód } 0,63 \text { marki) }\end{array}$ & \\
\hline & 5,89 marek $-4,64$ marki $=$ & 1,25 \\
\hline 611,70 & Fundacja na rzecz utrzymania wiecznej lampki & \\
\hline & $\begin{array}{l}600 \text { marek w zachodnio-pruskich listach zastawnych } \\
\text { zdeponowanych na } 3 \frac{1}{2} \% \text { (roczny przychód } 21 \text { marek) }\end{array}$ & \\
\hline & $\begin{array}{l}\text { 11,70 marek zdeponowanych w kasie oszczędnościo- } \\
\text { wej w Lubawie na } 4 \% \text { (roczny przychód } 0,46 \text { marki) }\end{array}$ & \\
\hline & 21,46 marek -6 marek $=$ & 15,46 \\
\hline 3030,16 & Fundacja nieznanego dobroczyńcy z Pelplina & \\
\hline & $\begin{array}{l}2400 \text { marek zdeponowanych w zachodnio-pruskich } \\
\text { listach zastawnych na } 3 \frac{1}{2} \% \text { (roczny przychód } 84 \\
\text { marki) }\end{array}$ & \\
\hline
\end{tabular}


Tab. 3. cd.

\begin{tabular}{|c|c|c|c|}
\hline & & $\begin{array}{l}\text { 630,16 marek zdeponowanych w kasie oszczędno- } \\
\text { ściowej w Lubawie na } 4 \% \text { (roczny przychód 25,20 } \\
\text { marek) }\end{array}$ & \\
\hline & & 109,20 marek -105 marek $=$ & 4,20 \\
\hline & 100 & $\begin{array}{l}\text { Fundacja Sprengerów (Sprenger'sche Stiftung) zdepo- } \\
\text { nowana w kasie oszczędnościowej w Lubawie na } 4 \% \\
\text { (roczny przychód } 4 \text { marki) }\end{array}$ & \\
\hline & & 4 marki $-3,50$ marki $=$ & 0,50 \\
\hline & 522,50 & $\begin{array}{l}\text { Fundacja Kobierzyńskich (Kobierzyński’sche Stiftung) } \\
\text { zdeponowana w kasie oszczędnościowej w Lubawie na } \\
\text { 4\% (roczny przychód 20,88 marek) }\end{array}$ & \\
\hline & & 20,88 marek $-20,88$ marek $=$ & 0 \\
\hline & 300 & $\begin{array}{l}\text { Fundacja von Dąbrowskich (v. Dąbrowski’sche Sti- } \\
\text { ftung) zdeponowana w kasie oszczędnościowej w Lu- } \\
\text { bawie na } 4 \% \text { (roczny przychód } 12 \text { marek) }\end{array}$ & \\
\hline & & 12 marek $-10,50$ marek $=$ & 1,50 \\
\hline & 150 & $\begin{array}{l}\text { Fundacja Franza Angermeiera (Franz Angermeier'sche } \\
\text { Stiftung) zdeponowana w kasie oszczędnościowej } \\
\text { w Lubawie na } 4 \% \text { (roczny przychód } 6 \text { marek) }\end{array}$ & \\
\hline & & 6 marek $-5,25$ marek $=$ & 0,75 \\
\hline & 250 & $\begin{array}{l}\text { Fundacja Peus-Angermeierów (Peus-Angermeier'sche } \\
\text { Stiftung) zdeponowana w kasie oszczędnościowej } \\
\text { w Suszu na } 3 \frac{11}{2} \% \text { (roczny przychód } 8,75 \text { marek) }\end{array}$ & \\
\hline & & 8,75 marek $-8,75$ marek $=$ & 0 \\
\hline & 75 & $\begin{array}{l}\text { Fundacja Spanke (Spanke’sche Stiftung) zdeponowana } \\
\text { w kasie oszczędnościowej w Suszu na 3풍 (roczny } \\
\text { przychód 2,62 marki) }\end{array}$ & \\
\hline & & 2,62 marki $-2,12$ marki $=$ & 0,50 \\
\hline & 300 & $\begin{array}{l}\text { Fundacja Koernerów (Koerner'sche Stiftung) zdepo- } \\
\text { nowana w zachodniopruskich listach zastawnych na } \\
\text { 31/2\% (roczny przychód } 10,50 \text { marek) }\end{array}$ & \\
\hline & & 10,50 marek -9 marek $=$ & 1,50 \\
\hline & 150 & $\begin{array}{l}\text { Fundacja Schmidtów (Schmidt'sche Stiftung) zdepo- } \\
\text { nowana w kasie oszczędnościowej w Suszu na 31/2\% } \\
\text { (roczny przychód 5,25 marek) }\end{array}$ & \\
\hline & & 5,25 marek $-4,25$ marki $=$ & 1 \\
\hline IV & & Datki na tacę oraz do puszek & 136 \\
\hline $\mathrm{V}$ & & Podzwonne & 1,80 \\
\hline VI & & $\begin{array}{l}\text { Za miejsce na cmentarzu (brak katolickiego cmen- } \\
\text { tarza) }\end{array}$ & 0 \\
\hline
\end{tabular}


Tab. 3. cd.

\begin{tabular}{|l|l|c|}
\hline VII & Na świece, światło i lampy & \\
\hline & przy ślubach, chrztach i wprowadzeniach & 7,60 \\
\hline & przy pogrzebach & 0 \\
\hline & w czasie mszy św. & 6,50 \\
\hline VIII & Na paramenty kościelne i utensylia & 2 \\
\hline IX & Za wynajęte miejsca w kaplicy & 20 \\
\hline$X$ & Inne & 18 \\
\hline & na celebracje liturgiczne w więzieniu & 378,28 \\
\hline & 14192,17 & SUMA: \\
\hline
\end{tabular}

Źródło: GStA PK, XX. HA Hist. StA Königsberg, Rep. 2 Oberpräsident der Provinz Ostpreußen II, Nr 2331, k. 139v-141.

Dochody kuracji suskiej opierały się przede wszystkim na wsparciu finansowym pochodzącym spoza placówki duszpasterskiej (w sumie 85,40 marek), prowizji uzyskanej z lokowanego kapitału (100,98 marek), ofiarach na tacę oraz do puszek (136 marek), a także opłatach za rezerwację miejsc (20 marek). Wprawdzie wartość kapitału kasy kościelnej czy też fundacji erygowanych przy kuracji opiewała na 14 192,17 marek, jednak znaczna część prowizji otrzymywanej z tego źródła podlegała opłatom za obsługę wspomnianych rachunków oraz wtórnej lokacji, co najczęściej wynikało $\mathrm{z}$ treści aktów erekcyjnych tych fundacji. W powyższej tabeli odnotowano to działanie w postaci równania matematycznego po scharakteryzowaniu każdej z nich. Całkowity dochód kuracji stanowił zaledwie 378,28 marek. Nie dysponowała ona wpływami wynikającymi z dzierżawy nieruchomości gruntowych ani z opłat związanych z pogrzebem.

W tabeli nr 4 wyszczególniono rozchody kuracji w Suszu, które wynikały z planu budżetowego przyjętego na lata 1894-1899.

Tab. 4. Rozchody kuracji suskiej na podstawie planu budżetowego na lata 1894-1899

\begin{tabular}{|l|l|c|}
\hline Lp. & \multicolumn{1}{|c|}{ Tytuł rozchodu } & $\begin{array}{c}\text { Roczna } \\
\text { wartość } \\
\text { wydatków } \\
\text { (w markach) }\end{array}$ \\
\hline I & Na pensje i opłaty: & \\
\hline & Skarbnikowi kasy kościelnej na materiały piśmienne & 3 \\
\hline
\end{tabular}


Tab. 4. cd.

\begin{tabular}{|l|l|c|}
\hline & $\begin{array}{l}\text { Dziekanowi miejscowego dekanatu na materiały i opłatę pocztową } \\
\text { przy rewizji kaplicy }\end{array}$ & 5,50 \\
\hline & $\begin{array}{l}\text { Rekompensata na rzecz organisty (z darowizny 24 marki i z kasy } \\
\text { kościelnej 12 marek) }\end{array}$ & 36 \\
\hline & Wynagrodzenie kalikanta & 6 \\
\hline & Na utrzymanie czystości kaplicy i bielizny kościelnej & 20 \\
\hline & Za bicie w dzwony i odgarnianie śniegu & 36 \\
\hline & Dziekanowi za oleje święte wraz z opłatą pocztową & 2 \\
\hline & $\begin{array}{l}\text { Dziekanowi za egzemplarz „Amtliches Kirchenblatt für die Diözese } \\
\text { Culm }\end{array}$ & 2 \\
\hline & Swiadczenia komunalne za nieruchomość użytkowaną przez kurację & 0,60 \\
\hline & Dziesięcina na rzecz Kościoła ewangelickiego & 1,28 \\
\hline II & Na wino mszalne i hostie & 45 \\
\hline III & Na świece, utrzymanie wiecznej lampki i kadzidło & 75 \\
\hline IV & Na utrzymanie kościelnego inwentarza & 39 \\
\hline V & Na prace budowlane, remonty i ubezpieczenie od pożaru: & 49,60 \\
\hline & Na prace budowlane i remonty & 25,40 \\
\hline & Na ubezpieczenie od pożaru & 25 \\
\hline VI & Na lokowanie kapitału & 6,90 \\
\hline VII & Inne (opłaty pocztowe, sprawy kościelne) & 378,28 \\
\hline & SUMA: & \\
\hline & SsA & \\
\hline
\end{tabular}

Źródło: GStA PK, XX. HA Hist. StA Königsberg, Rep. 2 Oberpräsident der Provinz Ostpreußen II, Nr 2331, k. 141v-142.

Najwięcej środków finansowych przeznaczano na świece, utrzymanie wiecznej lampki, kadzidło (75 marek), na prace budowlane i remonty (49,60 marek), a także na zakup wina mszalnego, hostii (45 marek). Za wykonywanie obowiązków organisty płacono 36 marek, natomiast kalikanta - jedynie 6 marek. Bilans dochodów (tab. 3) oraz rozchodów (tab. 4) kuracji suskiej, ujęty w planie budżetowym na lata 1894-1899 nie wykazywał wartości ujemnych, co stanowiło dowód płynności finansowej opisywanej placówki duszpasterskiej.

Kolejnym czynnikiem rozpatrywanym w procesie transformacji kuracji w pełnoprawną parafię było należyte wynagrodzenie duszpasterza danej placówki, a zwłaszcza gwarancje jego stałych przychodów. Reprezentacja wspólnoty katolickiej z Susza i okolic, wybrana 4 lutego 1900 r., zadeklarowała, że po przekształceniu kuracji w parafię, wynagrodzenie 
proboszcza będzie składało się z następujących wpływów: z funduszy biskupich - 1095 marek, z fundacji - 406 marek, z funduszu dotacyjnego (Dotationsfonds) - 148 marek oraz z dochodów okolicznościowych 175 marek. W sumie jego roczną pensję określano na 1824 marki ${ }^{46}$.

Na początku 1901 r. rejencja kwidzyńska informowała nadprezydenta prowincji zachodnio-pruskiej w Gdańsku, że biskup chełmiński zwolnił przyszłą wspólnotę parafialną od współfinansowania pensji w suskiej placówce duszpasterskiej ze względu na potrzebę spłaty zadłużenia wynikającego z budowy nowego obiektu sakralnego. Ordynariusz zapewniał zresztą o dotacji opiewającej na 1095 marek rocznie, która stanowiłaby wsparcie na rzecz utrzymania tamtejszego duszpasterza, jak również pracowników kościelnych ${ }^{47}$. Tymczasem wartość podatku dochodowego płaconego przez katolickich mieszkańców Susza w 1900 r. spadła do 636 marek (zapewne podano otrzymaną, a nie zakładaną wartość podatku) ${ }^{48}$. W czerwcu 1901 r. ogłoszono, że podatek dochodowy członków przyszłej parafii wynosi 1024,48 marek, z czego mieszkańcy Susza płacili 861,80 marek $^{49}$. Należy nadmienić, że zdaniem przedstawicieli rejencji kwidzyńskiej, uzyskanie pełni praw parafialnych przez kurację suską oznaczałoby zgodę na polonizację niemieckiego powiatu i to za państwowe środki finansowe ${ }^{50}$.

Po przyznaniu katolickiej placówce duszpasterskiej w Suszu praw parafii misyjnej Ministerstwo Wyznań Religijnych, Oświaty i Zdrowia poinformowało rejencję kwidzyńską, że z racji wygospodarowania środków finansowych z budżetu państwa przewidzianego na rok fiskalny 1908 r., na rzecz tzw. kapitału fundacji proboszczowskich (zwanego kapitałem dotacyjnym) zostanie jej przekazana kwota 31000 marek, czyli równowar-

${ }^{46}$ GStA PK, XX. HA Hist. StA Königsberg, Rep. 2 Oberpräsident der Provinz Ostpreußen II, Nr 2331, k. 135v, 137-137v.

${ }^{47}$ GStA PK, XX. HA Hist. StA Königsberg, Rep. 2 Oberpräsident der Provinz Ostpreußen II, Nr 2331, k. 68v. Na temat budowy kościoła pw. św. Rozalii w Suszu zob. A. Rzempołuch, dz. cyt., s. 103-107; M. Jodkowski, Przyczynek do dziejów katolickiej placówki duszpasterskiej w Suszu na przełomie XIX i XX wieku (w druku).

${ }^{48}$ GStA PK, XX. HA Hist. StA Königsberg, Rep. 2 Oberpräsident der Provinz Ostpreußen II, Nr 2331, k. 69v.

${ }^{49}$ GStA PK, XX. HA Hist. StA Königsberg, Rep. 2 Oberpräsident der Provinz Ostpreußen II, Nr 2331, k. 81v.

${ }^{50}$ GStA PK, XX. HA Hist. StA Königsberg, Rep. 2 Oberpräsident der Provinz Ostpreußen II, Nr 2331, k. 70. 
tość wkładu wniesionego przez stronę kościelną. Kalkulacja tego kapitału wynikała z ustawy dotyczącej wynagrodzenia katolickich proboszczów, w której minimalne dochody określono na 1800 marek, a maksymalne na 4000 marek. Warto wspomnieć, że jej przyjęcie wiązało się z mocą wsteczną naliczania nowych stawek od 1 kwietnia 1908 r. $^{51}$ Prawdopodobnie postawiono jednak warunek, że bez transformacji parafii misyjnej w pełnoprawną parafię opisywana placówka duszpasterska nie otrzyma funduszy państwowych na wsparcie kapitału fundacji proboszczowskich ${ }^{52}$.

\section{ZAKOŃCZENIE}

Próba transformacji kuracji suskiej w pełnoprawną parafię na przełomie XIX i XX wieku nie przyniosła oczekiwanych rezultatów, mimo wzniesienia świątyni i gwarancji dotyczących finansowania placówki duszpasterskiej. Nieprzychylne stanowisko zarówno lokalnego magistratu, jak również przedstawicieli rejencji kwidzyńskiej, prowincji zachodnio-pruskiej czy też rządu w Berlinie, opierało się z pewnością nie tylko na czynnikach demograficznych (zbyt mała liczba wiernych), ale również na uprzedzeniach konfesyjnych oraz obawie przed polonizacją Susza i okolic. Parafia mogłaby stać się także potencjalnym środowiskiem krzewienia świadomości narodowej wśród ludności polskojęzycznej. Przedstawiciele administracji państwowej wyrazili zgodę na ustanowienie w tym mieście jedynie parafii misyjnej. Nie posiadała ona jednak przywilejów przysługujących pełnoprawnym parafiom. Jej funkcjonowanie było uzależnione w dużej mierze od pomocy finansowej diecezji chełmińskiej, stowarzyszeń, a także organizacji katolickich.

Streszczenie. Starania o nadanie osobowości prawnej placówce duszpasterskiej w Suszu podejmowano już w 1868 r. Zabiegano wówczas o swobodę obrotu środków finansowych przez tamtejszą katolicką stację misyjną. Pierwszy duszpasterz suski - ks. Franz Albert Loeper, urzędujący w tym mieście od 1870 r., ponowił wcześniejszą próbę.

${ }^{51}$ GStA PK, XX. HA Hist. StA Königsberg, Rep. 2 Oberpräsident der Provinz Ostpreußen II, Nr 2331, k. 190.

${ }^{52}$ Por. GStA PK, XX. HA Hist. StA Königsberg, Rep. 2 Oberpräsident der Provinz Ostpreußen II, N. 2331, k. 194. 
Wniosek o uzyskanie praw parafialnych przedłożono władzom państwowym za pośrednictwem biskupa chełmińskiego już w 1873 r., niestety bezskutecznie. Po kilku latach wznowiono procedurę, dokonując uprzednio wyboru przedstawicieli lokalnej wspólnoty katolickiej. Ostatecznie władze państwowe udzieliły pozwolenia na erygowanie parafii misyjnej w Suszu, co nastąpiło w 1902 r. Poza prawem zrzeszania wiernych, zarządzania własnym majątkiem i swobodą szafowania sakramentami, nie posiadała jednak pełni praw parafialnych. Nie mogła zatem ubiegać się o przywileje finansowe udzielane przez państwo pruskie. Kolejne prośby o zmianę statusu prawnego tejże placówki duszpasterskiej odrzucano, motywując nieprzychylne stanowisko m.in. spadkiem liczby wiernych. Obawiano się przy tym polonizacji Susza, jego okolic oraz krzewienia tendencji narodowościowych wśród polskojęzycznej społeczności. Mimo wieloletnich zabiegów nie udało się zmienić statusu prawnego opisywanej parafii misyjnej. Jej funkcjonowanie było uzależnione od pomocy finansowej ze strony diecezji chełmińskiej, stowarzyszeń i organizacji katolickich.

Słowa kluczowe: polityka wyznaniowa w Prusach; relacje państwo-Kościół w Prusach na przełomie XIX i wieku; diecezja chełmińska; diaspora katolicka; Susz.

Abstract. An attempt to grant parish rights to the Catholic pastoral institution in Susz in the turn of the $19^{\text {th }}$ and $20^{\text {th }}$ centuries. A contribution to the research on the Prussian religious policy. Attempts to grant the pastoral institution in Susz a legal entity were made as early as in 1868. At that time, efforts were made to allow free circulation of financial resources by the local Catholic mission station. The first priest of Susz, Franz Albert Loeper, who served in the town since 1870, repeated an earlier attempt. An application to obtain parish rights was submitted to the state authorities by proxy of the Bishop of Culm in 1873, unfortunately to no avail. After a few years the process was renewed; before that, representatives of the local Catholic community had been elected. Finally, the state authorities gave a permission to found a mission parish in Susz, which happened in 1920. Apart from the rights to unite worshippers and administer its property as well as the freedom to give sacraments, it did not have full parish rights. Therefore it could not apply for the financial privileges granted by the Prussian state. Subsequent requests to change the legal status of this institution were rejected; the unfavourable response was motivated by, among others, the decreasing number of worshippers. There was a serious fear that it would lead to the Polonization of Susz and the surrounding areas, as well as to the promotion of national identity within the Polish-speaking community. Despite many years of attempts, the legal status of the said parish was not changed. Its function depended on the financial help from the Bishopric of Culm and from Catholic societies and organisations.

Keywords: religious policy in Prussia; state - Church relationship in Prussia in the end of the $19^{\text {th }}$ and in the beginning of the $20^{\text {th }}$ century; Bishopric of Culm; Catholic diaspora; Susz. 